\title{
Whole-soil warming alters microbial community, but not concentrations of plant-derived soil organic carbon in subsoil
}

Other Conference Item

Author(s):

Zosso, Cyrill; Ofiti, Nicholas O.E.; Soong, Jennifer L.; Solly, Emily F.; Torn, Margaret S.; Huguet, Arnaud; Wiesenberg, Guido L.B.; Schmidt, Michael W.I.

Publication date:

2021

Permanent link:

https://doi.org/10.3929/ethz-b-000516735

Rights / license:

Creative Commons Attribution 4.0 International

Originally published in:

EGUsphere, https://doi.org/10.5194/egusphere-egu21-4921 
EGU21-4921

https://doi.org/10.5194/egusphere-egu21-4921

EGU General Assembly 2021

(c) Author(s) 2021. This work is distributed under

the Creative Commons Attribution 4.0 License.

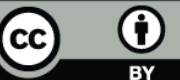

\section{Whole-soil warming alters microbial community, but not concentrations of plant-derived soil organic carbon in subsoil}

Cyrill Zosso ${ }^{1}$, Nicholas O.E. Ofiti ${ }^{1}$, Jennifer L. Soong ${ }^{2}$, Emily F. Solly ${ }^{3}$, Margaret S. Torn ${ }^{2}$, Arnaud Huguet $^{4}$, Guido L.B. Wiesenberg ${ }^{1}$, and Michael W.I. Schmidt ${ }^{1}$

${ }^{1}$ Soil Science and Biogeochemistry Unit, Department of Geography, University of Zurich, Zurich, Switzerland

(cyrill.zosso@geo.uzh.ch)

${ }^{2}$ Climate and Ecosystem Science Division, Lawrence Berkeley National Laboratory, Berkeley, CA, USA

${ }^{3}$ Group for Sustainable Agroecosystems, Department of Environmental Systems Science, ETH Zurich, Zurich, Switzerland

${ }^{4}$ Sorbonne Université, CNRS, EPHE, PSL, UMR METIS, F-75005 Paris, France

Soils will warm in near synchrony with the air over the whole profiles following global climate change. It is largely unknown how subsoil (below $30 \mathrm{~cm}$ ) microbial communities will respond to this warming and how plant-derived soil organic carbon (SOC) will be affected. Predictions how climate change will affect the large subsoil carbon pool (>50\% of SOC is below $30 \mathrm{~cm}$ soil depth) remain uncertain.

At Blodgett forest (California, USA) a field warming experiment was set up in 2013 warming whole soil profiles to $100 \mathrm{~cm}$ soil depth by $+4^{\circ} \mathrm{C}$ compared to control plots. We took samples in 2018 , after 4.5 years of continuous warming and investigated how warming has affected the abundance and community structure of microoganisms (using phospholipid fatty acids, PLFAs), and plant litter (using cutin and suberin).

The warmed subsoil (below $30 \mathrm{~cm}$ ) contained significantly less microbial biomass (28\%) compared to control plots, whereas the topsoil remained unchanged. Additionally below $50 \mathrm{~cm}$, the microbial community was different in warmed as compared to control plots. Actinobacteria were relatively more abundant and Gram+ bacteria adapted their cell-membrane structure to warming. The decrease in microbial abundance might be related to lower SOC concentrations in warmed compared to control subsoils. In contrast to smaller SOC concentrations and less fine root mass in the warmed plots, the concentrations of the plant polymers suberin and cutin did not change. Overall our results demonstrate that already four seasons of simulated whole-soil warming caused distinct depth-specific responses of soil biogeochemistry: warming altered the subsoil microbial community, but not concentrations of plant-derived soil organic carbon. 